\title{
What is 'the sign of the Son of man in heaven' (Mt 24:30)?
}

\begin{abstract}
Author:
Marius $\mathrm{Nel}^{1}$

\section{Affiliation:}

${ }^{1}$ Research Unit of the Faculty of Theology, North-West University, Potchefstroom Campus, South Africa

\section{Correspondence to:} Marius Nel

Email:

nel.marius1@gmail.com

Postal address:

PO Box 12373, Bendor Park

0713, South Africa

Dates:

Received: 21 Aug. 2014

Accepted: 14 Jan. 2015

Published: 30 Mar. 2015

How to cite this article: Nel, M., 2015, 'What is 'the sign of the Son of man in heaven' (Mt 24:30)?', In die Skriflig 49(1), Art. \#1876,

9 pages. http://dx.doi. org/10.4102/ids.v49i1.1876

\section{Copyright:}

(C) 2015. The Authors.

Licensee: AOSIS

OpenJournals. This work is licensed under the Creative Commons Attribution

License.
\end{abstract}

Read online:

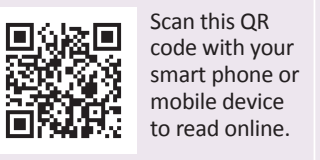

What does the 'sign of the Son of man in heaven' in Matthew 24:30 denote? In broad terms, there are two ways to interpret the phrase. Firstly, that the coming of the Son of man in the clouds is the 'sign of the Son of man' and the phrase explains the sign, much like lightning is depicted as a sign in Matthew 24:27. Secondly, the sign is interpreted in terms of various objects that will precede the coming of the Son of man. What is the significance of the term, 'the sign of the Son of man?' In the discussion the phrase juxtaposed with its context in the Gospel, the apocalyptic discourse with its judgement on the established religious institution of the Jews as represented by the temple in Jerusalem, before its exegesis is discussed. The purpose is to describe the possible denotations for 'the sign in heaven of the Son of man'.

Wat is 'die teken van die Seun van die mens' in die hemel (Matt 24:30)? Waarop dui die 'teken van die Seun van die mens in die hemel' in Mattheus 24:30? Breedweg is daar twee maniere om die frase te interpreteer. In die eerste plek is die koms van die Seun van die mens in die wolke die 'teken van die Seun van die mens'; die frase verduidelik die teken soos weerlig as 'n teken soos dit in Mattheus 24:27 gebruik word. Tweedens kan die teken geïnterpreteer word ten opsigte van die verskillende voorwerpe wat die koms van die Seun van die mens voorafgaan. Wat is die betekenis van die term, 'die teken van die Seun van die mens?' In die bespreking word die frase teenoor sy konteks in die Evangelie geplaas, naamlik Jesus se apokaliptiese diskoers met sy oordeel oor die gevestigde godsdienstige instelling van die Jode soos deur die tempel in Jerusalem verteenwoordig is. Hierna word die eksegese van die teks bespreek. Die doel is om die moontlike denotasies van 'die teken in die hemel van die Seun van die mens' te beskryf.

\section{Introduction}

Matthew 24:301 forms part of the apocalyptic discourse introduced by a discourse on the denunciation of the Pharisees (23:1-36), with seven woes decrying their hypocrisy before lamenting Jerusalem's downfall (23:37-39). The apocalyptic discourse (24:1-25:46) follows and it ends with the transitional formula in $26: 1-2 .^{2}$

\section{Matthew's apocalyptic discourse}

Some remarks about the apocalyptic discourse of the Gospel of Matthew are necessary to provide the context for the phrase in $24: 30 .^{3}$ In his apocalyptic discourse (24-25), Matthew devotes far more space than Mark or Luke to explicating the events that the disciples may expect surrounding the breaking down of the stones of the Jerusalem temple (24:1-2) and the (eventual) coming of the Son of man. The discourse follows directly on the controversy between Jesus and the Pharisees (23), with Jesus' words sounding as a refrain throughout the passage: Ovjai

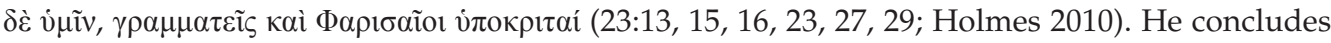

\footnotetext{
1.Further references to Matthew will be indicated only by chapters and verses.

2.DeSilva (2004:239) outlines the Gospel of Matthew in relation to the five discourses that mark it, apart from the infancy narratives $(1: 1-2: 23)$ that forms a prologue and the passion narratives $(26: 3-28: 20)$ as the epilogue. In the first part (3:1-7:29), the narrative $(3: 1-4: 25)$ is followed by the discourse of the Sermon on the Mount $(5: 1-7: 27)$ and concluded by a transitional formula (7:28-29). In the second part $(8: 1-11: 1)$, the missionary discourse $(9: 36-10: 42)$ follows on the narrative $(8: 1-9: 35)$ and concludes with a transitional formula (11:1). The discourse of the parables of the kingdom $(13: 1-52)$ follows on the narrative $(11: 2-12: 50)$ with the concluding formula in 13:53 in the third part (11:2-13:53). In the fourth part (13:54-19:1) the discourse of the regulations for church life (18:1-35) follows on the narrative in 13:54-17:27, and the transitional formula in 19:1. The last part (19:2-26:2) contains a discourse on the denunciation of Pharisees (23:1-36) with seven woes decrying their hypocrisy before lamenting Jerusalem's downfall (23:37-39) and the Apocalyptic discourse (24:1-25:46) following the narrative in 19:2-22:46 and ending with the transitional formula in 26:1-2. Matthew 24:30 forms part of the Apocalyptic discourse.

3.Apocalyptic is used to refer to the worldview found among apocalyptic groups that sometimes produce a literary document called an
} apocalypse (Van Aarde 2002:119). 
by judging their behaviour in 23:33: ö The teachers of the (Mosaic) law and the Pharisees represent the official Jewish religious institution of Jesus' day and the temple serves as a symbol for this institution. The Gospel repudiates the entire traditional Jerusalem power structure, argues Myers (1988:425). Jesus takes on the politics of domination itself. Wink (1984:104-105) reasons that the spiritual powers should not be interpreted as separate heavenly or ethereal entities, but as 'the inner aspect of material or tangible manifestations of power', referring to the actual powers determining the political, social, economic and religious world surrounding Jesus and his disciples. According to Wink (1984:105), these powers should not be limited to the special category of spiritual powers, but rather be interpreted in terms of the dual aspect of their physical or institutional manifestation on the one hand, and their inner essence or spirituality on the other. Popular speech refers to these powers as 'the powers that be':

In all these cases, the simultaneity of heavenly and earthly events witnesses to the perception, mythically couched, that there is more to events than what appears. The physical actors and institutions are only the outer manifestation of a whole field of powers contending for influence. (Wink 1984:107)

The battle is against the spirituality of institutions, against the ideologies and legitimations that prop them up, against the greed and covetousness that give them life, and against the idolatry of individual egocentricities (Wink 1984:140). When Jesus announces in 24:2, Oỏ $\beta \lambda \varepsilon \dot{\pi} \varepsilon \tau \varepsilon \tau \alpha \tilde{\tau} \tau$

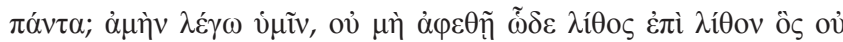
$\kappa \alpha \tau \alpha \lambda \nu \theta \dot{\sigma} \sigma \varepsilon \tau \alpha 1$, he expresses his judgement over the Jerusalem religious establishment, and this is how he concludes his teaching about the teachers of the law and the Pharisees (23).

The reference to the fig tree found in 24:32-35 is also connected with Jesus' condemnation of the religious institution. He curses the fig tree in 21:18-22, with the fig tree associated in the Jewish mind with Israel as a symbol of God's people (cf. Hs 9:10; Nah 3:12). The parable explains that God expects his people to bear fruit in its time. The cursing of the fig tree is an acted parable ${ }^{5}$ about God's judgement of his own people and their religious institutions, and especially on the religious leaders that caused Jews to

4.Some researchers divide Matthew 23 and 24 and rather talk of six discourses in Matthew. However, the link between 23 and 24 consists in Jesus' controversy with the scribes and Phaisees as representatives of the official in Jew controversy with the scribes and Pharisees as representatives of the official Jewish religious institution end in wis not be able to escape being condemned to hell (23:33), and his admonishment of Jerusalem as the city that kills prophets and stones those who are sent to it: 'Your house will be deserted' (23:38). The next chapter contains Jesus' prediction that not a single stone will be left on another when the disciples look at the temple buildings. Jesus continues his condemnation and judgement of official Jewish religion with his apocalyptic discourse in 24 and 25 (cf. Mills 1999:192).

5.The parable is 'a story that never happened but always does - or at least should' (Crossan 2012:5). It is a metaphor expanded into a story, or more simply, a parable is a metaphorical story (Crossan 2012:7): A parable is a story whose artistic surface structure allows its deep structure to invade one's hearing in direct contradiction to the deep structure of one's expectation. It is an attack on the world, a raid on the articulate (Crossan 1974:98). Van der Watt (2009:328) refers to Eugene Peterson's articulate (Crossan 1974:98). Van der Watt (2009:328) refers to Eugene Peterson's picture of a parable as subversive, absolute, ordinary, and secular. When people listened to parables they saw that it did not threaten their own sovereignty, the imaxed their 'Dienses and the Imagination. 'Die Bedeutung einer Metapher erschopft sich nicht in einer einzigen Interpretation. Metaphern haben grundsätzlich einen Bedeutungsüberschuss und setzen immer wieder neue Bedeutungen sich heraus' (Erlemann 2006:38) Metaphors are at the heart of parables. stumble and betray their God (11:12-14) and their temple as symbol of their deviated religious allegiance. ${ }^{6}$

A second remark is that the prophetic material in the apocalyptic discourse refers to events not only at hand (as in the case of 24:2, 15-16), but also to those stretching far into the future (as in $24: 14,29-31 ; 25: 6,31-46$ ). ${ }^{7}$ The author utilises the technique of prophetic foreshadowing so that the widely separated mountain peaks of historic events merge before one's eyes and are seen as one (Hendriksen 1973:846). Two events are intertwined. 'Looking back to the destruction of the Temple in $70 \mathrm{CE}$, Matthew describes both the death of the Messiah and the vision of the coming of the Son of Man' (Van Aarde 1999:688). He sees the judgement of Jerusalem, which includes the destruction of the temple in the fall of $70 \mathrm{CE}$, and the final judgement at the close of the world's history as though it refers to one event. Jerusalem's approaching catastrophe of destruction becomes a type of the tribulations that believers would experience at the end of the dispensation; Jesus paints the circumstances that would appear at the end of history in colours borrowed from the destruction of Jerusalem by the Romans (Grosheide 1954:355-356). This also explains the prediction that these events would take place within the current generation (24:34). If the prophetic prediction of the destruction of Jerusalem is seen together with Jesus' return, the meaning is clear: as the destruction would take place before many of the hearers die, so the same pattern of sudden, swift, merciless judgement will accompany his return at the end of time (Campbell 2008:149). ${ }^{8}$ France (1985:347) thinks that the destruction of the temple, viewed as an act of divine judgement, vindicates the authority of Jesus over the Jewish establishment which has rejected him in the same sense as when he sends his angels, exercising a divine prerogative (Turner 2008:700).

The main emphasis in the apocalyptic discourse is the necessity that believers should always be on the alert, actively working to serve their Master's interests, and staying faithful to him and his orders, as demonstrated in 24:3, 23, 25, 42; and the entire 25 .

6.The audience realises that the temple, like the fruitless fig tree, is condemned to destruction for failing to attain its purpose to be a house of prayer for all peoples. They must adopt Jesus' attitude toward the temple by rejecting it as a den of robbers, just as he has rejected it and left it twice with his disciples (Heil 1997:78). robbers, just as he has rejected it and left it twice with his disciples (Heil 1997:78). lack of importance for Jewish leaders that gentiles should be part of their worship of YHWH.

7.Referring to Matthew 24 and 25, Blomberg (1992:562) writes: 'Its structure and interpretation are notoriously complex' and continues with describing a possible option of structure. Interpreters differ in their analysis of the apocalyptic discourse. However, two conclusions are crucial, namely that no one knows or can predict when Jesus will come back (24:36), and all the preliminary signs leading up to but not including Christ's actual return were fulfilled in the generation immediately following Christ's death $(24: 33-34 ; 1992: 562)$. Christians of all ages are called to remain faithful and expectant of the Parousia since 70 CE completed all the things necessary for Christ to come back.

8.Matthew's conception of time amounts to 'the end is announced as having begun', and he relates it to the destruction of Jerusalem and especially the temple, the implied interim period and the coming of the Son of man (Van Aarde 1999:672). The The author understands that he and his addressees are already living in the endtimes (Van Rensburg 2011:472). The arrival of the last days does not imply that the find had come. The 201 says final salvation for God's people and judgement for their enemies was yet to take place at some later stage in redemptive history (Phillips, Janse van Rensburg \& Van Rooy 2012:4) 


\section{Lastly, 24 and 25 contain the following ten episodes}

Matthew 24:1-3 explains the setting for the discourse, with Jesus responding to his disciples' amazement at the beauty of the temple by asserting that not one stone in the temple will be left in place, and the disciples' question of when this will happen and what the sign of Jesus' coming and of the end of

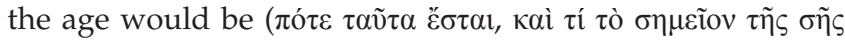

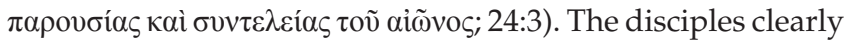
identify the destruction of the temple with Jesus' second coming, which they also identify with the end of the existing order (or age) (Blomberg 1998:453). 'The language is allusive rather than specific, and depends for its force on a familiarity with Old Testament imagery which is unfortunately not shared by all modern readers! (France 1985:347)'. It could also be that Matthew, being the only evangelist inserting the reference to Jesus' parousia, takes a wider look at the end of the world. The fall of the temple is thus not the end of the world, as was assumed in Jewish apocalyptic; the end will only take place at the parousia of Jesus. ${ }^{9}$

Matthew 24:4-14 contains Jesus' answer, predicting the arrival of false Christs and false prophets, wars and rumours of wars, famines, earthquakes, persecution, apostasy, lawlessness, and the chilling of mutual love. These

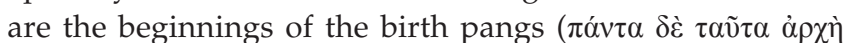

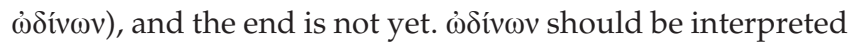
in terms of its usage in the Hebrew Bible where it is used to refer to judgement and Israel's suffering, and especially the destruction of a city, and the city most frequently referred to is Jerusalem, likened to a woman in labour (cf. Is13:8; 26:17; 66:8-9; Mi 4:9-10; Hs 13:13; Jr 4:31; 6:24; cf. Rm 8:22) ${ }^{10}$ Pitre (2004:276-278) adds that 'birth pangs' can also refer to the coming of the Messiah, pointing to Micah 5:2-4 and Jeremiah 30:5-9. The Messiah will come forth after the birth pangs of God's people. Birth pangs is a technical term in Jewish apocalyptic thought used also to refer to eschatological rebirth (Schweizer 1970:269). These signs are part of God's eschatological process and the implication is that He determines the process. The same image is found in one of the Thanksgiving Hymns from Qumran, which describes the advent of a messianic figure in terms relating to childbearing: 'Like a woman in travail with her first-born child, upon whose belly pangs have come and grievous pains' (1QH11:7-8 [formerly 3:7-8] quoted in Vermes 2003:292). Kleiber (2010:248-249) discusses another consideration: 'Diese Leiden sind nicht sinnlose Quälerie, sondern durch sie hindurch wird Gott neues Leben schenken.' Can one infer from this description that there will be a period of relief after the birth pangs, or that it is the final birth pains that come just before the baby is born? (Schweizer 1970:269). But first the

9. When applied to a king or other prominent dignitary, the term for Jesus' coming (parousia) was a quasi-technical expression that implied considerable demands for preparation on the part of the local populace' (Keener 1997:352).

10.Rabbinic teaching speaks of a suffering preceding the final end and calls it 'the birth pangs of the Messiah' (Anderson 1976:292-293). Cf. Geddert's (1989:174) birth pangs of the Messiah' (Anderson 1976:292-293). Cf. Geddert's (1989:174) their discipleship obedience is redemptive and part of the birth pangs, not only that of Jesus.

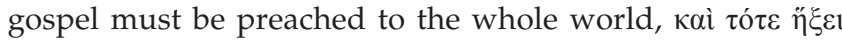

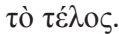

With the preaching of the gospel in 24:14 as the first

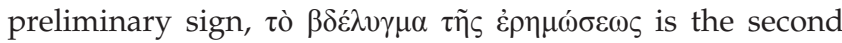
sign (discussed in 24:15-29) occurring immediately before the appearance of the sign of the Son of man (24:29-30). ${ }^{11}$ Even when this happens believers should not be deceived to follow false Christs and false prophets (24:24). ${ }^{12}$ Christ's coming will be sudden and visible everywhere, resembling a lightning flash seen from one horizon to the other (24:27) and will follow only after mankind will have deteriorated morally and spiritually to such an extent that it will resemble carrion ready to be devoured by vultures (24:28).

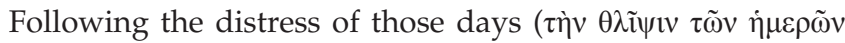

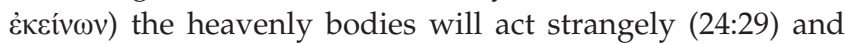

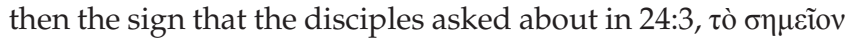

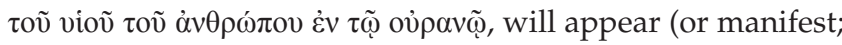
cf. Mills 1999:193) on the clouds with power and great glory (Turner 2008:700). The angels will gather the elect from everywhere with a trumpet call (24:30-31), portraying Jesus as divine (Keener 1997:352). ${ }^{13}$

Believers should learn the lesson from the fig tree, namely that when its branch becomes tender people know the summer is near, and when believers see the events climaxed by the appearance of the desolating sacrilege they should know that the fall of Jerusalem and its temple is near (24:32-35).

Matthew 24:36-44 stress the necessity of being always ready because nobody knows when the day and hour of Jesus' coming would be, as nobody knew when the flood would occur in Noah's day and the home-owner does not know when the thief would try to break into his home. Hagner (1995:720) emphasises that what Jesus is telling his disciples tends more to engage their caution than to satisfy their curiosity, more to prepare them for the events that should happen than to give them a distinct idea of the events themselves.

Readiness means faithfulness, demonstrated by the parable of the faithful and the wicked or unfaithful servants in $24: 45-51 .{ }^{14}$

11.Cf. the sign of the Noahic covenant, the rainbow $($ Gn $9: 12-13,17)$, the sign of the Abrahamic covenant, circumcision (Gn 17:11), as well as the sign of Jonah (Luk 11:30), referring to Jesus's resurrection, but also Jesus's refusal to do signs as demanded by the people (Mt 12:38-39; 16:1-4).

12.Jesus concedes that the false prophets and false Christs shall be successful: they shall deceive many $(24: 5)$ and if it were possible, even the elect (24:24; cf. Keener 1997:345).

13.France (1985:348) makes the provocative remark that angeloi might refer to human preachers of the gospel throughout the world, because they gather the chosen into the kingdom, rather than out of it. The reference is not, therefore, as in 13:41, to the final judgement, but to the worldwide growth of the church, which is consequent on the ending of Israel's special status, symbolised in the destruction of the temple (France 1985:349). It might also be taken in its normal sense of angels, in which case it refers to the supernatural power which lies behind such preaching.

14.Botha (1996:271) provides a timely warning that parables should be interpreted in terms of its context, in this case the apocalyptic discourse. He (ibid:272) is of the opinion that the meanin of the parables in opinion that the meaning of the parables in Mathew $24-25$ is not in the counse how to wait but rather in the self-defintion, of those who wait and who do not wait. Those who do not wait are 'in their synagogues' contra those who are in Christ. The parables are concerned with the theological problems concerning Jesus and Judaism, and the appropriation of biblical traditions (Botha 1996:283). 
Christ's return should be awaited and believers must always be prepared for it, as demonstrated in the parable of the five foolish and five thoughtful girls (25:1-13).

The message about believers' preparedness is reinforced by using a second parable, of the talents (25:14-30).

The coming of the Son of man is depicted again in 25:31-46 as a shepherd separating the sheep from the goats, and rewarding the righteous sheep with eternal life due to their loving service to Christ's brothers ( $\dot{\varepsilon} v i ̀$ oov $\tau \omega v \tau \tilde{\omega} v \dot{\alpha} \delta \varepsilon \lambda \varphi \tilde{\omega} v$

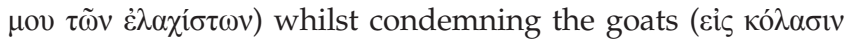
aióviov) because of their lack of this loving service.

\section{The sign of the Son of man in heaven}

\section{Signs preceding the coming of the Son of man}

At the time when desolating sacrilege will manifest in the temple, believers should be aware of persons claiming to be the Christ, for false Christs and false prophets will appear and perform great signs and miracles to deceive even the elect (24:23-24). Whilst Jesus performed true signs in his Father's Name, the nations rejected Him (cf. Jn 12:37-41; Jackson 2000:948). However, they will accept the signs performed by false Christs (Wiersbe 1996:89). Believers should remember that Christ warned them against deceivers (24:25). The Christ will not hide in the desert or the inner rooms (24:26); his coming will be like lightning that can be seen over the earth (24:27). Wherever there is a carcass, there the vultures will gather (24:28). ${ }^{15}$ The Judge will discover the wicked as surely as vultures find a carcass (Elwell 1995:294). ${ }^{16}$ Wiersbe (1996:89) brings the image into relation to the great battle of the end-times depicted in Revelation 19:17-19, and the carnage that will result.

The distress of those days will be followed by the darkening of the sun and moon, stars falling from the sky and heavenly bodies being shaken, unusual signs deduced from Isaiah 13:10; 34:4; Amos 8:9 and Joel 2:31; 3:15-16 (Van Aarde 2002:119). ${ }^{17}$

15.Several possibilities exist of what the meaning of 28 is. The coming of the Son of man will be as public and obvious as eagles or vultures circling over carrion (Davies \& Allison 2004:427); it indicates the moral corruption of the world, followed by judgement (Pfeiffer \& Harrison 1962:592), and the Son of man descending when the world becomes rotten with evil; the eschatolo when the world becomes rotten with evil, the eschatological tribulation will be concluded by vultures devouring the flesh of the wicked dead, as in Revelation $19: 17-18$; the body is Jesus, the vultures or eagles the disciples; or the eagles are
angels, based on the verbal connection with 31 (Chrysostom equated the eagles with the heavenly hosts; Davies \& Allison 2004:428).

16.In terms employed by the author of 2 Thessalonians, the world is the domain of Satan's man, the Antichrist, the lawless one (2 Th 2:8). Whilst many will be corrupted by false prophets, the Son of man will come quickly and unexpectedly to sit in judgement over the corruption of the world.

17. Hendriksen (1973:862) deduces that Matthew 24 must be interpreted in the light of the style that is characteristic of that type of literature, apocalyptic, and provides the most significant references from the Hebrew Bible: sun and moon (Is 13:10; Ezk 32:7; Jl 2:10, 21; 3:15); stars (Is 34:4); powers of heaven (Is $34: 4$ II 2:10; Hg 2:6, 21); sign (Zch 12:10, 12); coming on clouds (Dn 7:13-14); angels J 2:10; Hg 2:6, 21); sign (Zch 12:10, 12); coming on clouds (Dn 7:13-14); angels with trumpet (Is 27:13); gathering from four winds (Dt 30:4; Zch 2:6). McCuistion, Warner and Viljoen (2014:1) emphasises that a Jewish viewpoint dominates the structure of the Gospel. A striking resemblance comes from a contemporary source, Pseudo-Philo's Book of biblical antiquities: I will command the years and charge the times, and they shall be shortened, and the stars shall be hastened, and the light of the sun make speed to set, neither shall the light of the moon endure (Liber Antiquitatum Biblicarum 19:13; aangehaal in Vermes 2003:298).
Matthew divides the parousia of the Son of man into three scenes: the appearance of the sign of the Son of man, followed by his coming with great power and glory, and then the gathering of the elect by his angels. In this way, Matthew makes the parousia more vivid and dramatic than the other synoptics. Mark (13:24-25) limits it to two scenes, the coming of the Son of man and the gathering of the elect and Luke (21:27) restricts it to the saying of the coming of the Son of man (Rengstorf 1971:236). In Mark 13:27, it is the Son of man who is said to gather, but in Matthew the verb has been made plural, so that it is the angels who gather (Nolland 2005:985).

\section{Sign of the Son of man}

Immediately after the changes mentioned in 24:29, the sign of the Son of man shall be seen. ${ }^{18} \sigma \eta \mu \varepsilon i ̃ v$ is used in the sense of sign, characteristic, or mark (Rengstorf 1971:201), with the basic meaning that in a specific situation that cannot be repeated. $\sigma \eta \mu \varepsilon \tilde{o} v$ states or indicates a possibility or intention or the indispensability of a definite human reference, with always a kind of pointer to the responsibility of the human(s) involved in the relevant situation (Rengstorf 1971:231).

According to Matthew 12:38, some of the scribes and

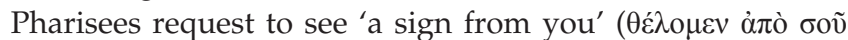
$\sigma \eta \mu \varepsilon i ̃ o v ~ i \delta \varepsilon i v)$. Jesus answers that an evil and adulterous generation seeks a sign, but no sign will be given except the sign of the prophet Jonah, who was three days and three nights in the belly of the great fish, illustrating how the Son of man will be three days and three nights in the heart of the earth (12:39-40). This is repeated in Matthew 16, where the Pharisees and Sadducees ask him to show them a sign from

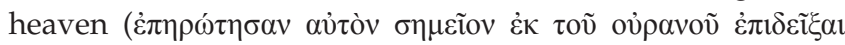

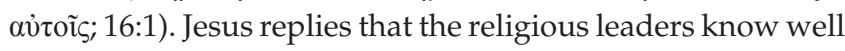
how to interpret the appearance of the sky, but they cannot interpret the signs of the times. He concludes again that an evil and adulterous generation seeks a sign, but no sign will be given except the sign of Jonah (16:2-4). In Matthew 24:3 it is his disciples who ask him what the sign of his coming and

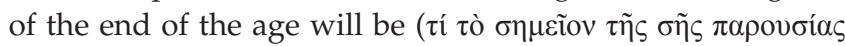

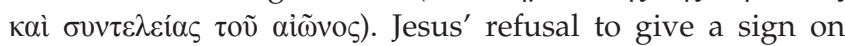
the request of the religious authorities might indicate his unwillingness to indicate what precisely he means with the sign of the Son of man that will appear in heaven (24:30; Luz 2005:108-109).

Matthew usually deletes the adverb $\varepsilon \dot{v} \theta \dot{\varepsilon} \omega \varsigma$ from his sources (Fuller 1966:157); his usage of the term in 24:29 emphasises the immediacy of Jesus' coming after the tribulation. Then the heavenly bodies will react strangely, leading to the sign of the Son of man. Jesus uses typical apocalyptic imagery of cosmic upheaval. According to Glasson (1964:299), he does not intend his language to be taken as a literal, scientific description of events, but as a vivid metaphor, as happens

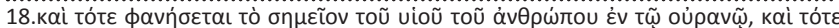
кó

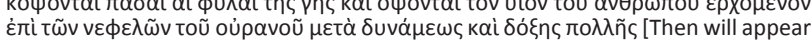
in heaven the sign of the Son of man, and then all the tribes of the earth will in heaven the sign of the Son of man, and then all the tribes of the earth will
mourn, and they will see the Son of man coming on the clouds of heaven with power and great glory]. 
when a person refers to 'earth-shaking developments'. ${ }^{19}$ His intention is to underline that from now on the universe can no longer continue as it had been (cf. Rv 6:12-17; 8:12) and that the cosmic and demonic powers often associated in pagan religions with the heavenly bodies are overthrown. The metaphors in Matthew 24:29 echo Isaiah 13:10; 34:4, without quoting it. ${ }^{20}$

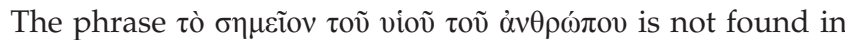
Mark and Luke, who simply say, 'And then they shall see the Son of man coming in clouds with great power and glory' (or: 'in a cloud with power and great glory'). Why would Matthew add these words left out by $\mathrm{Q}$ and Mark? (Luz 2005:47). ${ }^{21}$

Jesus already referred to signs that will precede his second coming; now he describes the last and greatest (Grosheide 1954:368). The saying of the sign of the Son of man is in itself mysterious. The context suggests that it refers to something that is so terrifying that it causes all people on earth to strike up a lament for themselves in their last distress (24:30; Rengstorf 1971:236).

Matthew's sign has been interpreted in different ways and

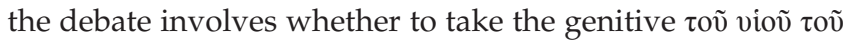

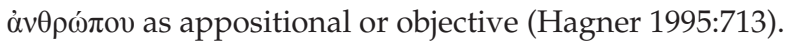

\section{Sign taken in appositional or epexegetical sense}

Taken in appositional sense, 'the sign' refers to the appearance of Christ himself in the clouds of heaven (2:12;

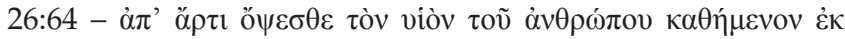

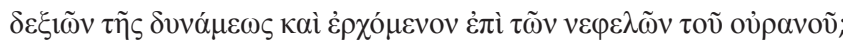
Dn 7:13,14), with power and glory, proving that he is the true Christ (or Messiah) and Judge of the whole world (in the sense of: the sign, namely, that is, who is, consisting of, the son of man; Luz 2005:108). Because Jesus does not depict the character of the sign, Grosheide (1954:368) argues that it probably refers to the parousia itself, the sign of all signs, when he appears in the clouds, coming with power and glory (cf. Mt 26:64). For this reason, Weber (2000:403) translates the phrase as 'the sign that is the Son of man', implying that Jesus himself will be the final sign as he ascends visibly to earth, an interpretation that in his opinion is supported by the rest

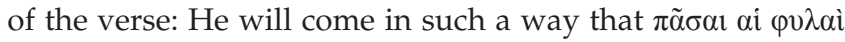
$\tau \tilde{\Upsilon} \varsigma \gamma \tilde{\eta} \varsigma$ will see him. 'Christ's brilliant self-manifestation will be a sign that he is about to descend in order to meet his

19. Hendriksen (1973:863) warns that although in apocalyptic pictures literalness must be avoided, at least some of it must be taken literally; otherwise, some apocalyptic images hold no meaning to the listener and reader. Hendriksen grounds a litera interpretation of Matthew 24 in 2 Peter 3:7-12. However, to reconcile the different passages from the New Testament with the presupposition that they describe the same events is risky. The genre of 2 Peter also differs from Matthew 24.

20.In evaluating possible intertextual relations the following questions should be asked: Which marked or unmarked quotations or allusions does Matthew use? Is there a difference between marked and unmarked quotations and allusions in Matthew? What happens if Matthew is read from the perspective of the macrotext of one of his quotations? What happens with the macrotext of a quotation or of one of his quotations? What happens with the macrotext of a quotation or relate texts with other texts, which Matthew may have known but did not explicitly relate texts with other texts, which Matt

21.The differences between Mark 13:26 and Matthew 24:30 are: 'in clouds' becomes 'on the clouds of heaven', bringing the text in line with Daniel 9:13; and 'great' is attached to 'glory' rather than 'power' (Nolland 2005:983). people while they ascend to meet him in the air' (Hendriksen 1973:864). This explanation, however, seems to confuse the sign and that which it represents (Williams 1909:469), the token of the Messiah and the Messiah himself, who comes afterward. The definite article, 'the sign' ( to imply something already well-known to the readers that denotes him, whereas his appearance could not be known beforehand.

\section{Sign in objective sense}

Taken in appositional sense, the sign has been taken by various researchers and commentators through the ages to refer to a variety of potential objects or events:

- The almost universal interpretation of the Church Fathers and early commentators (like Chrysostom, Hilary, Jerome \& Wordsworth - quotations and annotations in Lange \& Schaff 2008:428; cf. Higgins 1962, 3:380-382 defending the viewpoint) saw in the sign the cross of Christ manifesting in the heavens accompanying the appearance of the Son of man, which is indeed the ensign and standard of the gospel (France 1985:347). ${ }^{22}$ Chrysostom (1888; in Prevost \& Riddle's commentary on v. 30) writes:

'Then shall appear the sign of the Son of Man in Heaven', that is, the cross being brighter than the sun, since this last will be darkened, and hide himself, and that will appear when it would not appear, unless it were far brighter than the beams of the sun. (p. 24)

The cross characterises the Son of man, as the emblem of his humiliation and his triumph (Williams 1909:439). However, there is nothing in the apocalyptic discourse, the Gospel, or any intertextual reference that justifies the view that the sign of the Son of man refers to the cross of Golgotha, and in the light of the symbolic language of 29 we should not expect such a literal interpretation (France 1985:347):

- The phrase is interpreted as no other than what is described in the preceding verse, in 24:29: 'the sun will be darkened, and the moon will not give its light, and the stars will fall from heaven, and the powers of the heavens will be shaken'. ${ }^{23}$ However, 24:30 makes a distinction between the signs described in 29 by beginning 30 with

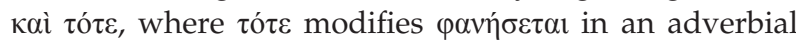
relation serving in a temporal sense.

\section{The sign may also be the lightning ( $\dot{\eta} \dot{\alpha} \sigma \tau \rho \alpha \pi \dot{\eta})$ of Matthew 24:27}

- The sign refers to a star heralding Christ's second coming, as happened when a star announced Jesus' birth to the wise men (2:2) (perhaps with reference to $\mathrm{Nm} 24: 17)$. It is

22.As Constantine would claim to see the sign of the cross in the clouds with the words, 'Hoc signo vinces' at the decisive battle at the Milvian Bridge when he conquered Maxentius' army that was three times as large as Constantine's (Kuiper 1951:23).

23.'And the powers of heaven will be shaken' finds no direct parallel in the Hebrew Bible but is similar to the statement in Joel 2:10 (cf also Is $34: 4 \cdot 13: 13 ; \mathrm{Hg} 2: 6,21$ ) The coming of the Son of man will be attended by unusual phenomena in the sky. The coming of the Son of man will be attended by unusual phenomena in the sky.
Apocalyptic imagery of this sort became commonly used in depicting the coming of eschatological judgement (Hagner 1995:713). 
arbitrary to find the denotation of the sign in a star and there is nothing to support it, especially as the meaning of the star would not be directly intelligible to all readers (Williams 1909:469).

- Since the apocalyptic words in 24:29 refer to what will happen at the Lord's return and echo Isaiah 13:10 and 34:4, which prophesy the fall of great political powers such as Babylon and Edom, the sign of 24:30 refers, according to Kapolyo (2006:1162), to the destruction of Jerusalem by the Romans. ${ }^{24}$

- As a banner or heavenly ensign it will introduce and accompany the appearance of the Son of man (cf. Isa 11:12; 18:3; 1QM 3:1-4:17). France (1985:347), Carson et al.

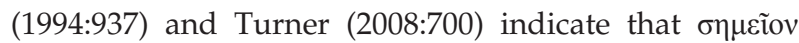
can also be translated as banner or standard as part of the military imagery for the triumph of the Son of man and recalling Isaiah 11:12; 49:22-23, and as a signal for the gathering of God's people.

The sign is an appearance resembling a man that was seen in the Holy of Holies during the siege of Jerusalem, according to one of the many fables that originated around the destruction of the temple (Collins 2007:613). Josephus' (Jewish Wars VI, 4) account of the events of 70 CE tells that when the temple was on fire, a large number of people had taken refuge on the one remaining portico of the outer court. When the Roman soldiers set fire to it, these people all perished. Josephus blames their destruction on a certain false prophet who had proclaimed that very day to the people of Jerusalem that God commanded them to go up to the sanctuary where they would receive 'signs of their deliverance' (Jewish Wars VI, 4). Josephus also remarks that numerous prophets were instigated by 'the tyrants' to create the expectation in the people of imminent divine aid (Jewish Wars VI, 5). The prophets supported the messianic leader, Simon son of Gioras, and they actually believed that God would intervene on their behalf. They interpreted a series

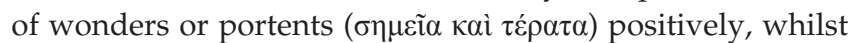
Josephus (Jewish Wars VI, 5.3) argues that these were actually signs of the coming destruction (cf. Collins 2007:613): ${ }^{25}$

- Pfeiffer and Harrison (1962:592) suppose that the sign refers to a bright light, or a kind of Shekinah (cf. with 24:30's $\delta o ́ \xi \eta \varsigma ~ \pi 0 \lambda \lambda \eta \tilde{s})$. The sign of the Son of man's departure (28:16-20) is on the same level as the departure of YHWH's glory from the temple (Ezk 10:3, 18; 11:23). In the same sense, the sign of his return involves his glory. His glory will doubtless be manifested at his second coming, as can be seen from 24:30, where it serves as a sign of the presence of God. In the context of 24, it cannot be recognised at once as the sign of the Son of man. Williams (1909:469) concedes that the meaning of the star as 'glory' would not be directly intelligible to all men.

- It may be seen as a sign for the gathering of the elect (24:31; cf. Dt 30:4; Mt 13:41; Van Zyl 2009:1407).

24.Alkier (2005:16) explains that as a reader of Isaiah, Matthew does what every reader does in the act of reading: he namely determines the text by his readings.

25. For example Josephus refers to the appearance of a comet that appeared during this time and lasted a year (Jewish Wars VI 5.3).
- The sign may be seen as a prediction of the harbingers and forerunners of Christ's coming, giving notice of his approach, like a light shining before him and a devouring fire (Ps 50:3; 1 Ki 19:11-12), and beams coming out of his hand (Hab 3:4; Davies \& Allison 2004:430).

- It may refer to the New Jerusalem that will accompany the parousia (Rv 21:2-3).

- Hendriksen (1973:865) adds that the sign serves to prove that Jesus is the Messiah of prophecy, as the glorious manner of his appearance will correspond exactly with that which was predicted concerning the Messiah in Daniel 7:13-14. ${ }^{26}$ The glory with which he appears 'will be a sign, a definite proof, of God's delight in his Son and of the justice of the cause of him who was once the Man of sorrows and acquainted with grief' (Hendriksen 1973:865).

Nolland's (2005:982) argument is valid in that the many speculative answers that have been offered as to what the sign might be are made possible only by ignoring the wording of the question in 24:3. And when one takes the question seriously, there are only two options, viz. to interpret it as the cosmic events of 29 or as nothing other than the visible appearing of the Son of man on the clouds of heaven. In either case, comprehensive visibility as stressed in 27 will be important. Nolland (2005:982) thinks that the most attractive option in relation to Matthew's source is of taking sign as ensign, as an eschatological ensign signalling muster for the final battle (cf. also Hagner 1995:713). In ancient Israel the horn of a ram was blown to rally the tribes for war. This act was accompanied by the raising of an ensign upon a hill. The ensign consisted of a wooden pole upon whose crosspiece was an insigne, most often of an animal. Isaiah 13:2-4 explains that $\mathrm{YHWH}$ will raise an ensign and call for war, and the root of Jesse will stand as an ensign for the peoples (Is 11:10; Davies \& Allison 2004:429).

\section{Future or past? ${ }^{27}$}

Matthew 24:29-31 is interpreted and translated by most commentators as if it were a description of the second coming in the future. However, a literal translation may also render, 'Then, at that time the sign of the Son of man will appear in the sky ...,' placing the event in the contemporary reader's past rather than their future. A case can then be made that the reference to the sign is to denote an event meaningful to Jesus' listeners (or Matthew's readers), because Matthew's Jesus states explicitly in verse 34: 'this generation will not pass away until all these things take place'. That generation did not see the expected second coming; for this reason Jesus must have referred to something that was contemporary to their circumstances. Jesus tells the high priest according to

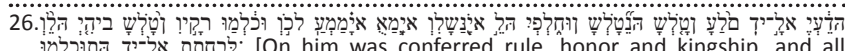

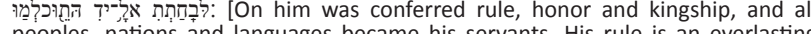
dominion which will never pass away, and his kingdom will never come to an end].

27.Preterists take the words as already fulfilled, and futurists as yet to be fulfilled. Preterist scholars interpret it as speaking of Jesus' enthronement in heaven or the destruction of Jerusalem and the temple on earth, but their arguments do not destruction of Jerusalem and the temple on earth, but their arguments do not
convince futurists, who insist that 31 describes the coming of Jesus to judge the earth (Turner 2008:698). 
Matthew 26:64 that 'from now on you will see the Son of man seated at the right hand of Power and coming on the clouds of heaven'. The priest did not see the second coming. A last argument is that when Jesus refers to the second coming in the second part of his discourse $(24: 27,37,39)$, he uses $\dot{\eta}$

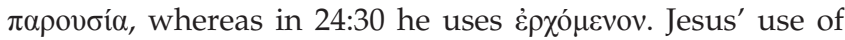
another word might indicate that he is not speaking of his

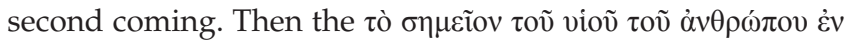
$\tau \tilde{\omega}$ oủpav $\tilde{\omega}$ might refer to the destruction of Jerusalem and the temple, and the tribulation or affliction $(\theta \lambda \tilde{i} \psi \mathrm{is})$ in verse 29 refers to the abomination of desolation depicted in verse

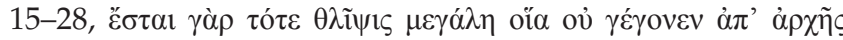

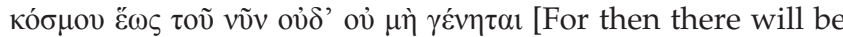
great tribulation, such as has not been from the beginning of the world until now, no, and never will be'; 24:21]. The sign of the Son of man is then interpreted as the sign of Jesus' vindication as the Messiah. The destruction of the temple implied that the Jewish system of sacrifices and ritual purity came to an end, indicating that Jesus is the true Saviour, and that Jerusalem is destroyed, implies that Jesus is crowned as King in heaven.

This argument, however, breaks down at the second part of verses 30 and 31:

the tribes of the earth will mourn when they see the Son of Man coming on the clouds of heaven and he will send out his angels with a loud trumpet call, and they will gather his elect from the four winds, from one end of heaven to the other ...

presumably to offer them something more than this world can. ${ }^{28}$ The reference to 'coming on the clouds of heaven' indicates God's presence (Ex 16:10; 19:9; 34:5; Lv 16:2; Nm 11:25), salvation (Ps 18:9-12) and judgement (Is 19:1; Nah 1:3, 5-6).

\section{Significance of 'the sign'}

Blomberg (1992:361) is of the opinion that it is not important to be able to decide amongst these different options what the sign of the Son of man comprises, since in any event the sign does not enable anyone to recognise the 'signs of the times'

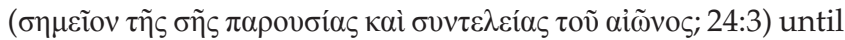
Christ is actually en route to the earth. What is important is that the sign of the Son of man is of such a kind and extent that present earthly-human existence reaches its ineluctable end therein. The sign proclaims this end unconditionally, and herein lays its true significance (Rengstorf 1971:237). Rengstorf (1971:237) describes the reference to the sign as complex and argues that it should be linked less with the person of the Son of man than with his apocalyptic function. Seen in this context, Rengstorf argues that the sign indicates that the parousia will not come directly, but will announce it first, and in the background is the certainty that the last act of history will begin with a final opportunity for conversion

28.The four winds-imagery is designed to include all directions, but it makes no comment on distance. The four winds occurring in Zecharih $2: 6$ and its LXX comment equivalent in 2:10 are of interest. The Gospel text seems to make use of the imagery of the gathering of the exlles in Israel (Nolland 2005:985-986). The point of Matthew's statement is the comprehensiveness (or universality) of the gathering of the saints (Hagner 1995:714). and faith. In his opinion this fits in well with the picture of the evangelist 'and his basic ethical position' (Rengstorf 1971:237). The question on how the sign of the Son of man is to be understood is only of secondary importance and it is not possible to say anything definite in reply. As in 24:15, Jesus leaves no clue as to how long it would take before he will come back. Instead he focuses on what will accompany his parousia.

\section{Weeping of the tribes}

When the people see the coming of the Son of man as clearly as a lightning bolt, they shall know unmistakably that he is

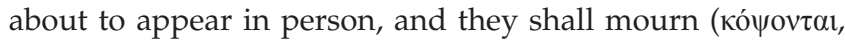
'shall beat the breast'; Weber 2000:403). ${ }^{29}$ Every eye shall see him, as predicted in Revelation 1:7 (Wiersbe 1996:89), and the reference to the trumpet blast emphasises that every ear will also hear him coming (Hendriksen 1973:865), announcing that the time has arrived (Nolland 2005:985). ${ }^{30}$ Not only the Jews, looking on him whom they pierced, shall mourn their blindness and impenitence (Zch 12:10-14; Is 53), but also all the nations who have rejected him. Revelation 1:7 use the term in the same way and a graphic depiction in Revelation 6:15-17 is added, whilst John 19:37 reapplies it to those who mourn the crucifixion. ${ }^{31}$ The mourning of the

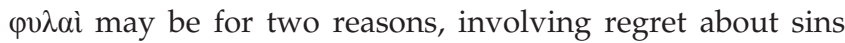
and contrition leading to repentance, or the realisation of the coming judgement, leading to weeping out of fear. ${ }^{32}$ It seems that Zechariah 12 refers to the first sense, and given that $\varphi v \lambda \alpha i$ more literally means tribes or families than nations (France 1985:348) and that the LXX uses it to refer to Israel; the mourning accompanying repentance of the people of Israel is probably in view here. ${ }^{33}$ This is the response of Israel when they see the vindication of 'him whom they pierced' (France 1985:348). This may then be a reference to the future repentance or conversion of Israel (cf. Rom 9-11), as Matthew 23:39 also hints with its reference to Psalm 118:26 (Davies \&

29. Mourn can also be translated as wail or lament recalling the customs of people of the Ancient Near East concerning death and burial, as well as exile (Mills 1999:193).
It came to be used for beating the breast in mourning and then more generally for any expression of mourning. The mourning envisaged here is probably grief at the any expression of mourning. The mourning envisaged here is probably grief at the prospect of
$(2005: 984)$.

30.Trumpet blasts announce for all to hear and with authority that 'a time of significance' has arrived, but without further context the use of the trumpet blast as such does not identify the nature of the significance. What is important here is that the trumpet blast is sent forth from heaven at the initiative of the Son of man (Nolland 2005:985).

31.Zechariah 12:12, 14 and Daniel 7:13-14 are combined in Matthew 24:30 and Revelation 1:7. Matthew includes an additional allusion to Zechariah 12:10, in . which the nations mourn (Keener 1997:352). Some researchers suggest that both passages draw on (1971:237) argues that origin. Rengstorf (1971.237) argues that too little attention has been paid to the fact that the order of the combined quotations varies in Matthew 24:30 and Revelation 1:7, with Revelation putting the Daniel reference first whilst Matthew puts Zechariah first, and Matthew not including the phrase, 'him whom they pierced', unlike Revelation 1:7 and John 19:37, which also quotes Zechariah 12:12 14. Matthew's dependence on tradition in using these texts cannot be proved and it is probably correct to assume that Matthew arranged the order deliberately. Matthew 24:30a should be ascribed to Jesus himself as its enigmatic character can hardly be explained as the work of a community or redactor.

32.Luke 21:25-26 adds that people will faint with fear and foreboding at the terror at what menaces the world, for the powers of heaven will be shaken, indicating that the term in at least Luke's view should be related to fear rather than repentance.

33.The term, $\phi u \lambda \alpha i$, calls to mind the twelve tribes, in which case tñ $ү$ ñऽ refers to the land Israel (Blomberg 1992:362; Carson et al. 1994:937). In keeping with Matthew's universal perspective, the tribes of the earth, which in the Hebrew Bible originally meant the tribes of Israel, are to be understood as all the nations of the earth (Hagner 1995:714). 
Allison 2004:431). Israel will experience national repentance, cleansing, and restoration, as Zechariah 12 predicts (Wiersbe 1996:89), or perhaps that is to read too much into the allusion (France 1985:348).

Whereas the cross shows that Christ died for people, the sign coming on the clouds shall show that he is judge and ruler over them (cf. Rv 1:7; 6:15-17). They shall see him (ő\%ovtal,

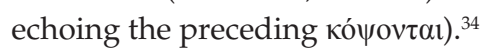

\section{The Son of man}

The sign is followed by, or is the advent of Christ, who refers to himself as 'the Son of man'. Bultmann (1972:38) divides the pronouncements of the Son of man into three categories, viz. those referring to Jesus' earthly activity; those referring to his passion; and those referring to his second coming. Jesus assumes the identity of the one who judges people at the end of time. In 26:63 the high priest asks Jesus whether he is the Messiah, the Son of the Blessed One, and Jesus answers affirmatively that people will see the Son of man seated at the right hand of the Power and coming with the clouds of heaven (26:64). Jesus' words function against the background of Daniel 7 with the Son of man coming with the clouds of heaven, and Psalm 110 where the Son of man sits at the right hand of God. The images of the Son of man condemned to death and the Son of man coming with the clouds of heaven explain one another. The roles assigned to the Son of man in Daniel 7:13-14 are divine - he will have dominion, glory, and kingship (Witherington 2001:51; Nolland 2005:985). France (1985:347) is of the opinion that the reference in Daniel 7:13 to the coming of the Son of man on the clouds do not speak of a 'coming to earth', but of coming to God to receive vindication and authority, as a symbol for a reversal of fortunes within history and at national level.

The Son of man will come in the clouds. Some have taken clouds to mean angels, because 16:27 suggests that the angels will accompany him (Williams 1909:469), but there is no need for the term to be considered metaphorical. Clouds always accompany theophanies (cf. Ps 18:10-12; Is 19:1; Dan 7:13; also Mt 26:64). ${ }^{35}$ The clouds can be understood metaphorically as the glory of God ( $\delta$ 'ó $\eta \varsigma \pi \mathrm{o} \lambda \lambda \tilde{\eta} \varsigma$ ) accompanying Jesus' parousia, or literally as clouds that will be the vehicle of his returning (Weber 2000:404)

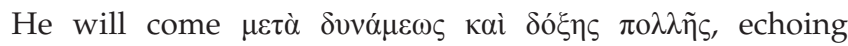
Daniel 7:13-14 and quoted again in Matthew 26:64 and alluded to in 10:23 (Hagner 1995:714). His coming will be accompanied with power (cum virtute multa - Vulgate). ${ }^{36}$ The

34.Grosheide (1954:368) speculates that the rhyme of the two words (ö 40 ovtai, kó $\psi$ ovtal) is intended by the author to emphasise the importance of the two concepts.

35. Hagner (1995:712) calls clouds the medium of participation, drawn by heaven from earth, distilled by heaven upon the earth. Christ ascended to heaven in a cloud (AC $1: 9,11$ ), and will in like manner come back (cf. Rv 1:7). A cloud is in Psalm 104:3 the judge's chariot, and according to Revelation 10:1 his robe and throne (cf. Rv 14:14).

36.Attempts to understand these words as referring not to the parousia but to the fall of Jerusalem (e.g. France 1985:347; Davies \& Allison 2004:429) is hardly convincing. It is apparently forced by Matthew's immediately but goes against the normal use of the language. The parousia of the Son of man has the marks the normal use of the language. The parousia of the Son of man has the marks character of this event (Hagner 1995:714). expression does not denote the attendant angels who are named in 24:31 but rather that he who on earth experienced only pain and humiliation will now be seen on the same earth with the splendour and majesty that belongs to him. The suffering and humiliation of the crucifixion looms large in Jesus' immediate future as he speaks (Blomberg 1992:362). ${ }^{37}$ His coming will be accompanied by a trumpet call, recalling a royal herald announcing the coming of the king with fanfare, but also the image from the Hebrew Bible of the trumpet call as the way YHWH gathered together his people, as happened at Mount Sinai (Ex 19:16), the holy mountain in Jerusalem (Is 27:12-13), and the eschatological march of God's army (Zch 9:14; Weber 2000:404), whilst the trumpet ordinance is found in Leviticus 25 (Hendriksen 1973:865). Israel's movements were also announced by trumpet signals (Nm 10; Jl 2:1, 11; Wiersbe 1996:89). Such passages refer to the regathering of Israel's exiles from the diaspora (Davies \& Allison 2004:431), but now those to be gathered are described as the elect $(22,24$; cf. also 22:14). The Son of man's people are no longer merely the members of the nation, but (as in 8:11-12) a chosen remnant, drawn from all corners of the earth (France 1985:348). When the significance of the Old Testament imagery is appreciated, 29-31 may be recognised 'as a highly symbolic description of the theological significance of the coming destruction of the temple and its consequences' (France 1985:349). 1 Corinthians 15:51-52 uses the same language, 'the trumpet will sound, and the dead will be raised imperishable, and we shall be changed' whilst 1 Thessalonians 4:15-18 states, 'the Lord himself will descend from heaven with a cry of command, with the voice of an archangel, and with the sound of the trumpet of God. And the dead in Christ will rise first.'

\section{Conclusion}

The phrase, 'the sign of the Son of man', can be understood in terms of an objective or appositional genitive, leading to two different ways to understand it. In its appositional sense, 'the sign' refers to the appearance of Christ himself in the clouds of heaven with power and glory, proving that he is the true Christ (or Messiah) and Judge of the whole world. In an objective sense the sign refers to a variety of potential objects and events: the cross of Christ manifesting in the heavens and accompanying the appearance of the Son of man, which is indeed the ensign and standard of the gospel; the darkening of the sun and the moon, the stars falling from heaven, and the powers of the heavens shaking; the lightning of 24:27; a star heralding his coming; the destruction of Jerusalem by the Romans; a final opportunity for conversion and faith; an appearance resembling a man seen in the Holy of Holies; a bright light, or a kind of Shekinah; a sign for the gathering of

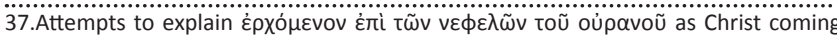
spiritually in judgement against Israel at the time of the destruction of the temple, leading to the conclusion that $24: 15-35$ as a whole refers to first-century events,

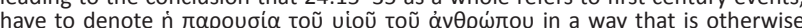
unparalleled in the New Testament (Blomberg 1992:363). The rest of the New unparalleled in the New Testament (Blomberg 1992:363). The rest of the New Testament evidently understands Christ's coming to earth as Jesus bringing all the faithful in heaven to join the faithful on earth, as Revelation 19:11-16 explains, heralded by a trumpet blast by an angel ( 1 Cor 15:52; 1 Th $4: 16$; Is 27:13). In 1 Thessalonians 4:16 the reference to the eschatological trumpet occurs in conjunction with the descent of the Lord from heaven, whereas in 1 Corinthian 15:52 the trumpet is associated with the resurrection of the dead, which Matthew makes no mention of here (Hagner 1995:715). 
the elect; a prediction of the harbingers and forerunners of Christ's coming, giving notice of his approach; or the New Jerusalem. It is not imperative to be able to decide amongst these options. What is important is that the sign of the Son of man proclaims the end of the world unconditionally, and herein lays its true significance.

\section{Acknowledgements Competing interests}

The author declares that he has no financial or personal relationship(s) that may have inappropriately influenced him in writing this article.

\section{References}

Alkier, S., 2005, 'From text to intertext: Intertextuality as a paradigm for reading Matthew', Hervormde Teologiese Studies 61(1\&2), 1-18.

Anderson, H., 1976, The Gospel of Mark, Oliphants, London. (New Century Bible).

Blomberg, C.L., 1992, Matthew, Broadman \& Holman, Nashville. (New American Commentary 22).

Blomberg, C.L., 1998, 'Matthew', in D.S. Dockery et al. (ed.), Holman Concise Bible Commentary, pp. 102-427, Broadman \& Holman, Nashville.

Botha, P.J.J., 1996, 'Gelykenisse in konteks: Aantekeninge oor Matteus 24:45-25:30', Skrif en Kerk 17(2), 271-291.

Bultmann, R., 1972, History of the synoptic tradition, Blackwell, Oxford

Campbell, I.D., 2008, Opening up Matthew, Day One Publications, Leominster.

Carson, D.A., France, R.T., Motyer, J.A. \& Wenham, G.J. (eds.), 1994, New Bible commentary: 21st century edition, 4th edn., Inter-Varsity, Leicester.

Chrysostom, J., 1888, 'Homilies of St. John Chrysostom, Archbishop of Constantinople on the Gospel according to St. Matthew', in G. Prevost \& M.B. Riddle (eds.), Saint Chrysostom: Homilies on the Gospel of Saint Matthew, transl. P. Schaff, pp. 1-187, Christian Literature, New York.

Collins, A.Y., 2007, Mark, Fortress, Minneapolis. (Hermeneia).

Crossan, J.D., 1974, 'The servant parables of Jesus', Semeia 1, 17-104.

Crossan, J.D., 2012, The power of parables: How fiction by Jesus became fiction about Jesus, HarperCollins, New York.

Davies, W.D. \& Allison, D.C., 2004, Matthew: A shorter commentary, Clark International, London.

DeSilva, D., 2004, An introduction to the New Testament: Contexts, methods \& ministry formation, Academic, Downers Grove.

Elwell, W.A., 1995, Evangelical commentary on the Bible, vol. 3, Baker Book House, Grand Rapids.

Erlemann, K., 2006, 'Die Selbstpräsentation Jesu in den Synoptischen Gleichnissen', in J. Frey, J. Rohls \& R. Zimmermann (eds.), Metaphorik und Christologie, pp. 37-52, Walter de Gruyter, Berlin. (Theologische Bibliothek Töpelmann 120).

France, R.T., 1985, Matthew, InterVarsity, Downers Grove. (Tyndale New Testament Commentaries)

Fuller, G.C., 1966, 'The Olivet discourse: An apocalyptic timetable', Wesleyan Theological Journal 28, 157-163.

Geddert, T.J., 1989, Watchwords: Mark 13 in Markan eschatology, Sheffield: Sheffield Academic. (Journal for the Study of the New Testament Supplement 26).

Glasson, T.F., 1964, 'The ensign of the Son of man (Matt. 24:30)', Journal of Theological Studies 15, 299-300. http://dx.doi.org/10.1093/jts/XV.2.299

Grosheide, F.W., 1954, Het Evangelie naar Mattheüs, Kok, Kampen. (Commentaar op het Nieuwe Testament).

Hagner, D.A., 1995, Matthew 14-28, Nelson, Nashville. (Word Biblical Commentary $33 B)$.

Heil, J.P., 1997, 'The narrative strategy and pragmatics of the temple theme in Mark', Catholic Biblical Quarterly 59, 76-100.
Hendriksen, W., 1973, Matthew, Banner of Truth Trust, Edinburgh. (New Testament Commentary).

Higgins, A.J.B., 1962-1963, 'The sign of the Son of man (Matt. 24:30)', New Testament Studies 9, 380-382. http://dx.doi.org/10.1017/S002868850000223X

Holmes, M.W., 2010, The Greek New Testament, SBL ed., Lexham, Logos.

Jackson, G.S., 2000, 'Are the "Nations" present in Matthew?' Hervormde Teologiese Studies 56(4), 935-948. http://dx.doi.org/10.4102/hts.v56i4.1797

Josephus, 1960, Complete works, transl. W. Whiston, Kregel, Grand Rapids.

Kapolyo, J., 2006, 'Matthew', in T. Adeyemo (ed.), Africa Bible commentary: A onevolume commentary written by 70 African scholars, pp. 1105-1170, WordAlive, Nairobi.

Keener, C.S., 1997, Matthew, InterVarsity Academic, Downers Grove. (The IVP New Testament Commentary Series).

Kleiber, W., 2010, Das Markusevangelium: Die Botschaft des Neuen Testaments, Neukirchener Theologie, Neukirchen-Vluyn.

Kuiper, B.K., 1951, The church in history, Eerdmans, Grand Rapids.

Lange, J.P. \& Schaff, P., 2008, A commentary on the Holy Scriptures: Matthew, Logos Bible Software, Bellingham.

Luz, U., 2005, Studies in Matthew, transl. R. Selle, Eerdmans, Grand Rapids.

McCuistion, P.R., Warner, C. \& Viljoen, F.P., 2014, 'The influence of Greek drama on Matthew's Gospel, Hervormde Teologiese Studies 70(1), Art. \#2024, 9 pages,

Mills, M.S., 1999, The life of Christ: A study guide to the gospel record, 3E Ministries, Dallas.

Myers, C., 1988, Binding the strong man: A political reading of Mark's story of Jesus, Orbis, Maryknoll.

Nolland, J., 2005, The Gospel of Matthew, Eerdmans, Grand Rapids. (The New International Greek Testament Commentary).

Pfeiffer, C.F. \& Harrison, E.F. (eds.), 1962, The Wycliffe Bible Commentary: New Testament, Moody Press, Chicago.

Phillips, G.Y., Janse van Rensburg, F. \& Van Rooy, H.F., 2012, 'Developing an integrated approach to interpret New Testament use of the Old Testament', In die Skriflig/In Luce Verbi 46(2), Art. \#50, 10 pages.

Pitre, B.D., 2004, 'The historical Jesus, the great tribulation and the end of the exile: Restoration eschatology and the origin of the atonement', PhD Dissertation, Nortre Dame University, Paris, (Unpublished).

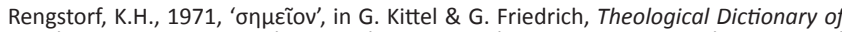
the New Testament, vol. 7, transl. G.W. Bromiley, pp. 200-269, Eerdmans, Grand Rapids.

Schweizer, E., 1970, The good news according to Mark, John Knox, Atlanta.

Turner, D.L., 2008, Matthew, BakerAcademic, Grand Rapids. (Baker Exegetical Commentary on the New Testament).

Van Aarde, A., 1999, 'Matthew 27:45-53 as the turning of the tide in Israel's history', Hervormde Teologiese Studies 55(2\&3), 671-692.

Van Aarde, A., 2002, 'Matthew and apocalypticism as the "mother of Christian theology": Ernst Käsemann revisited', Hervormde Teologiese Studies 58(1), 118142. http://dx.doi.org/10.4102/hts.v58i1.539

Van der Watt, J., 2009, Reading New Testament imagery, in A. du Toit (ed.), Focusing on the message: New Testament hermeneutics, exegesis and methods, pp. 305340, Protea Book House, Pretoria.

Van Rensburg, F.J., 2011, 'The eschatology of 1 Peter: Hope and vindication for visiting and resident strangers', in J.G. van der Watt (ed.), Eschatology of the New Testament and some related documents, pp. 472-492, Mohr Siebeck, Tübingen.

Van Zyl, H., 2009, 'Matteus' in F.J. van Rensburg \& M. Nel (eds.), Die Bybellenium, 'n eenvolumekommentaar, bl. 1337-1424, Christelike Uitgewersmaatskappy, Vereeniging.

Vermes, G., 2003, The authentic gospel of Jesus, Penguin, London.

Weber, S.K., 2000, Matthew, Broadman \& Holman, Nashville. (Holman New Testament Commentary 1).

Wiersbe, W.W., 1996, The Bible exposition commentary, vol. 1, Victor Books, Wheaton.

Williams, A.L., 1909, 'St. Matthew', in H.D.M. spence-Jones (ed.), The Pulpit Commentary, vol. 2, pp. 441-495, Funk \& Wagnalls, London.

Wink, W., 1984, Naming the powers: The language of power in the New Testament, vol. 1, Fortress, Philadelphia.

Witherington, B., 2001, The Gospel of Mark: A socio-historical commentary, Eerdmans, Grand Rapids. 